\title{
The Olefin Metathesis Reactions in Dendrimers
}

\author{
D. Astruc \\ Institut des Sciences Moléculaires, UMR CNRS 5255, Université Bordeaux I, 33405 Talence Cedex - France \\ e-mail: d.astruc@ism.u-bordeaux1.fr
}

Résumé - Les réactions de métathèse des oléfines dans les dendrimères - Les réactions de métathèse avec les dendrimères récemment étudiées dans notre groupe de recherche sont brièvement résumées dans cette micro revue. Celles-ci incluent les réactions qui impliquent des catalyseurs de métathèse métallodendritique comportant des terminaisons bis-phosphines coordonnées au catalyseur de métathèse centré sur le ruthénium (polymérisation) et les réactions de peralkylation des polyméthylarènes induites par complexation temporaire de ces arènes avec le greffon $\mathrm{CpFe}^{+}\left(\mathrm{Cp}=\eta^{5}-\mathrm{C}_{5} \mathrm{H}_{5}\right)$ couplée avec la métathèse (RCM et croisée), catalysée par les catalyseurs de Grubbs de première et seconde génération. Un exemple de la remarquable chemio-, régio- et stéréosélectivité de la métathèse croisée avec l'acide acrylique est mentionné, permettant d'accéder à des dendrimères hydrosolubles par fonctionnalisation des branches oléfiniques terminales. La revue mentionne également la polymérisation des alcynes terminaux par métathèse polymérisante dont la vitesse est considérablement accrue par couplage avec un catalyseur de transfert d'électron en chaîne.

\footnotetext{
Abstract - The Olefin Metathesis Reactions in Dendrimers - Olefin metathesis reactions catalyzed by $R u$ benzylidene catalysts involving polymers and dendrimers have been investigated in our research group and are briefly reviewed. Dendrimers have been loaded at their periphery with rutheniumchelating bis-phosphines, which leads to the formation of dendrimer-cored stars by ring-openingmetathesis polymerization (ROMP). $\mathrm{CpFe} e^{+}$-induced perallylation of polymethylaromatics $\left(\mathrm{Cp}=\eta^{5}-\mathrm{C}_{5} \mathrm{H}_{5}\right)$ followed by ring-closing metathesis (RCM) and/or cross metathesis (CM) leads to poly-ring, cage, oligomeric and polymeric architectures. In the presence of acrylic acid or methacrylate, stereospecific CM inhibits oligomerization, and dendritic olefins yield polyacid dendrimers. Tungsten-catalyzed polymerization of alkynes coupled with electron-transfer-chain catalysis leads to much faster and cleaner polymerization than with an 18-electron tungsten catalyst alone.
} 


\section{INTRODUCTION}

The understanding of the mechanism of olefin metathesis by Yves Chauvin $[1,2]$ has generated considerable efforts in the design of efficient catalysts [3, 4] and ended up in many applications [5-9]. The purpose of the present short review is to address alkene metathesis reactions in dendrimers. It is well known that alkene and alkyne metathesis reactions have produced new polymers [7]. The alkene and alkyne metathesis reactions mostly deal with low-molecular weight unsaturated substrates with the synthesis of pharmaceutically important products [5, 6] and polymers [5, 7]. Here, we are dealing with dendrimers for alkene metathesis of various types. In the first section, we discuss alkyne metathesis of terminal alkynes viewed from the side of electron-transfer-chain catalysis.

\section{METATHESIS OF TERMINAL ALKYNES: POLYMERIZATION IS CONSIDERABLY ACCELERATED BY COUPLING METATHESIS WITH ELECTRON-TRANSFER-CHAIN CATALYSIS}

The Chauvin mechanism for alkene metathesis has been extended by Katz to terminal alkyne polymerization metathesis (Scheme 1) [10a].

Katz et al. carried out initiation at $100^{\circ} \mathrm{C}$ for several days using $\left[\mathrm{W}(\mathrm{CO})_{6}\right][10 \mathrm{a}]$. In order to avoid such rather hard conditions, we designed coupling between electron-transferchain (ETC) ligand substitution and the tungsten catalysis. This allowed us to carried out the metathesis polymerization under ambient conditions. Thus, $\left[\mathrm{W}(\mathrm{CO})_{6}\right]$ was first heated in acetonitrile overnight yielding the stable, crystalline complex $\left[\mathrm{W}(\mathrm{CO})_{3}(\mathrm{MeCN})_{3}\right][10 \mathrm{~b}]$. This complex alone does not catalyze alkyne polymerization metathesis under ambient conditions, but addition of a very small amount of the ETC initiator ferrocenium hexafluorophosphate provides the hoped-for polymerization at $20^{\circ} \mathrm{C}$ in a few minutes. Indeed, we took into account the fact that the Chauvin-Katz mechanism requires introduction of two alkyne molecules into the $\mathrm{W}$ coordination sphere, one of which spontaneously isomerizes to vinylidene, which starts the square metathesis mechanism [11]. Exchange of the $\sigma$-donor $\mathrm{MeCN}$ ligand by the good $\pi$-acceptor alkyne ligand lowers the electron density at the metal center, which requires an oxidant rather than a reductant as the ETC initiator in order to provide a favorable driving force in the cross electron-transfer step of the ETC propagation cycle $[12,13]$. Note that the oxidant initiator ferrocenium must be used in catalytic amount (10\%) vs. the $\mathrm{W}$ catalyst which itself is used in 5\% catalytic amount. Indeed, if the ferrocenium salt was used in stoichiometric amount vs. the $\mathrm{W}$ catalyst, complete oxidation of the $\mathrm{W}$ catalyst inhibited the chain process [11] (Scheme 2).

\section{FROM RUTHENIUM BENZYLIDENE DENDRIMERS TO DENDRIMER-CORED STARS WITH NORBORNENE BY ROMP}

Metal-carbene metallodendritic complexes were known with four branches before our study and metathesis activity had been recorded [14] but good recyclability was still a challenge. The difficulty resided in the need to sustain both metathesis activity and stability of the metallodendrimer. Thus, we selected the ruthenium family of catalysts, and designed metallodendrimers containing ruthenium-benzylidene fragments located at the dendrimer periphery and chelating phosphine ligands on the branch termini. The choice of chelating phosphines may seem counter-intuitive, because the activity of Grubbs' catalysts involves the decoordination of a phosphine from these transbis-phosphine complexes [15]. Studies by the groups of Hofmann, Fog and Leitner, however, had shown the metathesis activity of cis-bis-phosphine ruthenium benzylidene catalysts [16]. We therefore used Reetz's bisphosphines derived from the commercial polyamine DSM

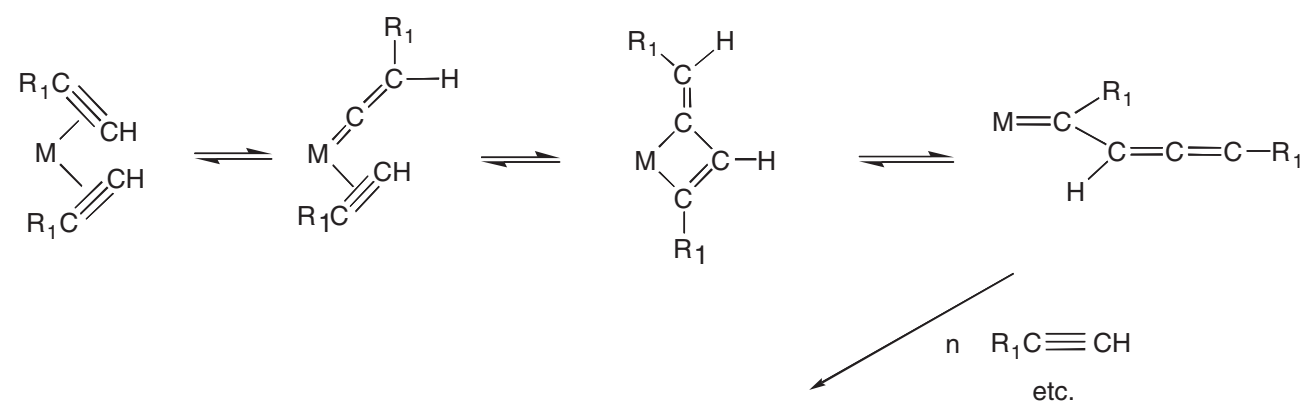

Scheme 1

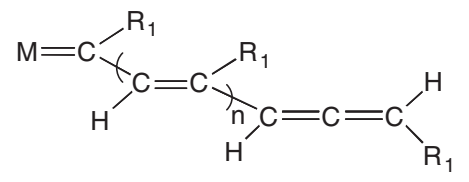

Chauvin-type mechanism proposed by Katz for alkyne polymerization [10a]. 


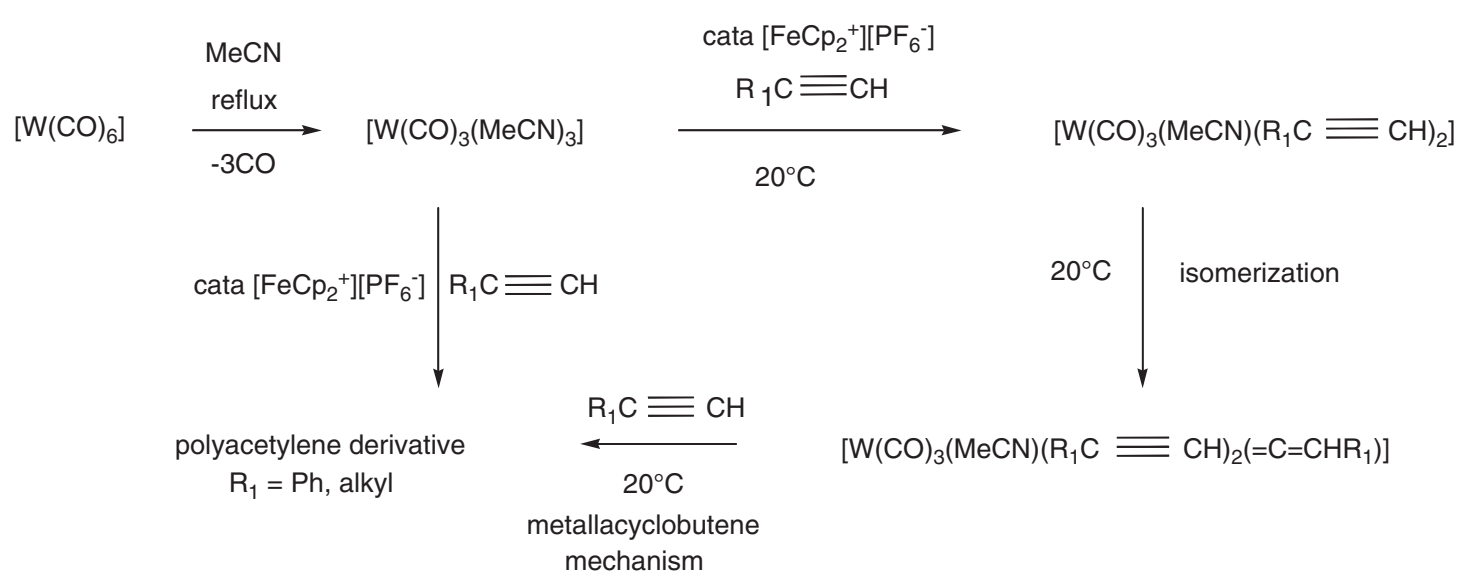

Scheme 2

Proposed mechanism for coupling ETC catalysis with metathesis polymerization catalysis.

dendrimers [17]. These dendritic bis-phosphines are useful and versatile in metallodendritic catalysis and provided the first recyclable metallodendritic catalysts [18]. They also very cleanly yielded, with two phenyl groups on each phosphorus atom, the first dendrimers decorated with clusters at the periphery by an efficient electron-transfer-chain reaction using $\left.\left[\mathrm{Ru}_{3}(\mathrm{CO})_{12}\right)\right]$ catalyzed by $\left[\mathrm{Fe}^{\mathrm{I}} \mathrm{Cp}\left(\eta^{6}-\mathrm{C}_{6} \mathrm{Me}_{6}\right)\right]$, 1, leading to the substitution of a carbonyl by a dendritic phosphine on each tether [18]. Related dendritic bis-phosphines with two cyclohexyl groups on each phosphorus were decorated with ruthenium benzylidene metathesis using Hoveyda's ruthenium benzylidene metathesis catalyst [19] as a starting point. These reactions provided the four generations of new, stable metallodendrimers containing ruthenium-benzylidene fragments at the periphery (Scheme 1) [20-22]. The fourthgeneration metallodendrimer containing 32 ruthenium-benzylidene fragments, however, was found to have a rather low solubility in common organic solvents, unlike the three firstgeneration complexes that respectively contained 4,8 and 16 ruthenium- benzylidene moieties. This weak solubility of the $32-\mathrm{Ru}$ dendrimer is presumably due to steric congestion at its periphery. Such steric congestion is also responsible for the decrease of the catalytic activity of $\mathrm{Ru}$ and Pd highgeneration dendritic catalysts shown in Scheme 3, even when these metallodendritic catalysts are soluble [23]. The X-ray crystal structure of the model mononuclear complex in which the dendritic branch was replaced by a benzyl group showed the distorted square pyramidal geometry and the classic geometric features of a $\mathrm{Ru}=\mathrm{C}$ double bond (Scheme 2). The oxygen atom of the isopropyl aryl ether group is not coordinated unlike in Hoveyda's complex 1. The fundamental organometallic chemistry of this monomeric model complex was also original and was reported elsewhere [20,21].

The three first generations of metallodendrimers 2 and the model complex were efficient catalysts for the ROMP of norbornene under ambient conditions, giving dendrimer-cored stars (Equation 1) [21, 22]. Analysis of the molecular weights by SEC gave data that were close to the theoretical ones, which indicated that all the branches were efficiently polymerized. Dendritic-cored stars with an average of about 100 norbornene units on each dendritic branch were synthesized with the three first generations of ruthenium-carbene dendrimers containing respectively 4,8 and $16 \mathrm{Ru}=\mathrm{C}$ bonds.

Two kinds of dendritic effect were found upon analysis of the kinetic data $[23,24]$ :

- The dendrimers were more efficient catalysts than the monomeric model complex. This could possibly be due to labilization of metal-phosphine bonds that is facilitated in dendrimers as compared to the monomer for entropic reasons. Indeed, DFT calculation showed that the catalytic process must involve decoordination of a phosphorus atom, since the interaction of the olefin with the diphosphine complex is non-bonding [21]. The dendritic ruthenium-benzylidene dendrimers were air-sensitive contrary to the monomer model complex, consistent with more rapid dissociation of the alkyl phosphine in the dendrimers than in the monomer.

- The efficiency of catalysis decreased upon increasing the dendrimer generation. This second dendritic effect is thus a negative one, and it is probably related to the more difficult access to the metal center due to the increasing steric effect at the dendrimer periphery when the generation increases.

The analogous ruthenium benzylidene dendrimers were very recently synthesized with two tertiobutyl groups on each phosphorus, and they were slightly more reactive ROMP catalysts for the polymerization of norbornene than those involving the cyclohexyl substituents [22]. These new dendritic ligands, in particular those of low generation (with up to 8 branches) proved very efficient in palladium catalysis [23]. 

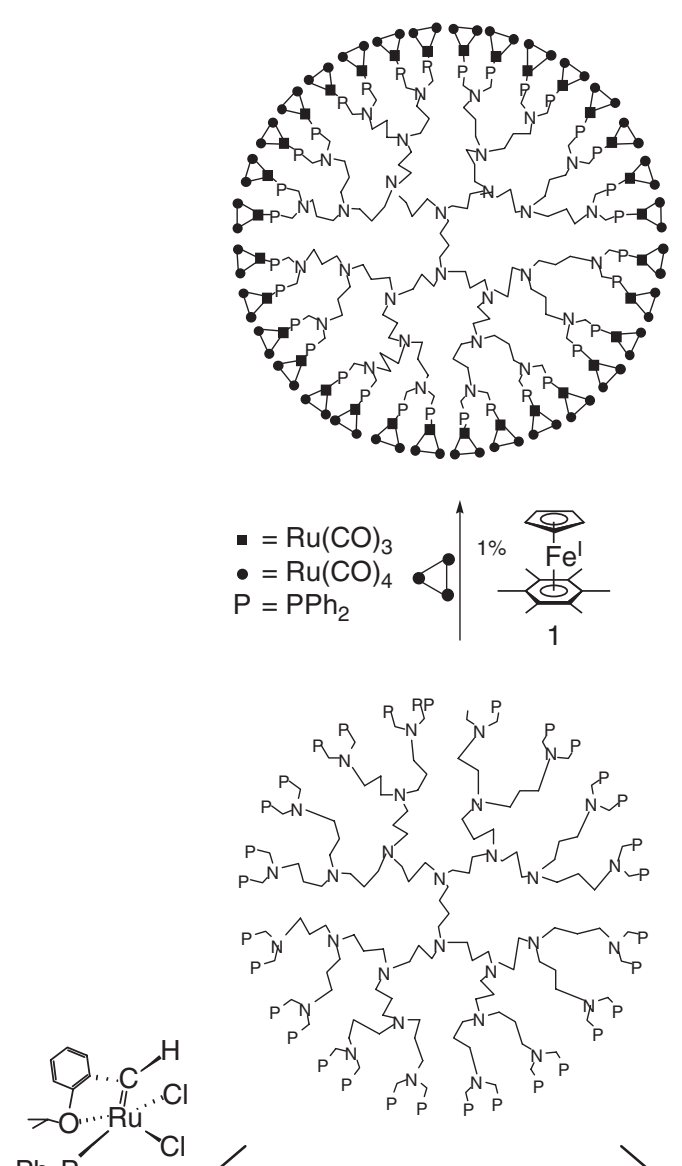

$\mathrm{Ph}_{3} \mathrm{P}^{-\mathrm{Cl} /} / \mathrm{P}=\mathrm{PCy}$ or $t-\mathrm{Bu}_{2} \quad \mathrm{P}=\mathrm{PCy}$ or $t-\mathrm{B}$

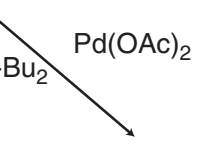

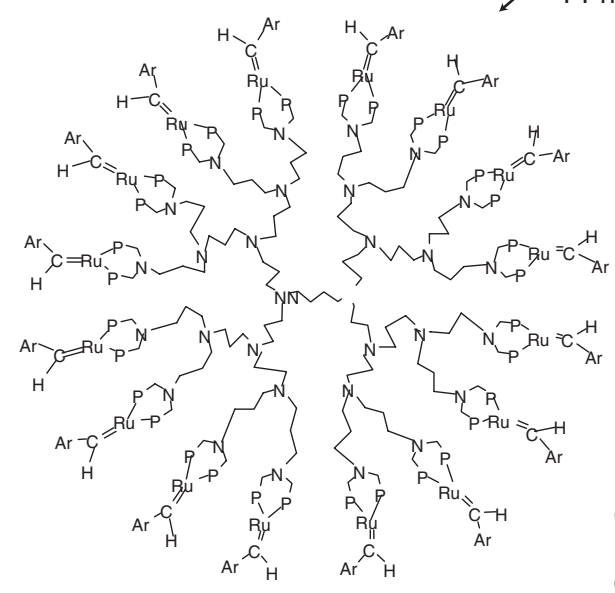

Cl ligands on $\mathrm{Ru}$ and

$R$ groups on $P$ omitted for clarity

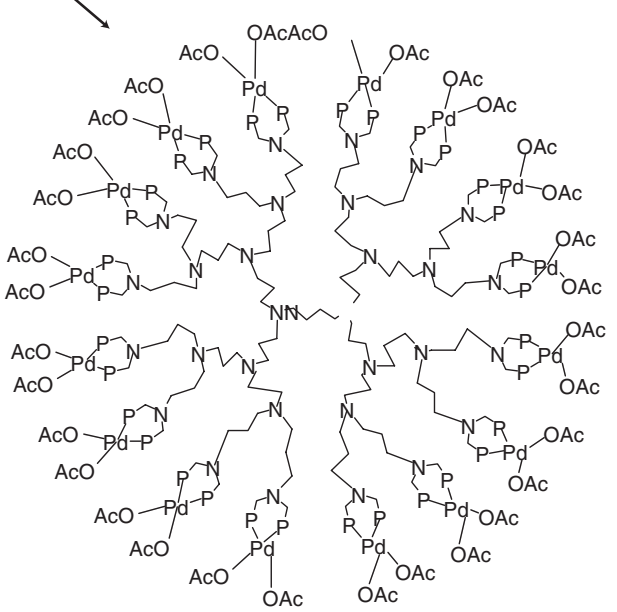

Scheme 3

Synthesis of third-generation metallodendrimers from various dendritic bis-phosphines. 


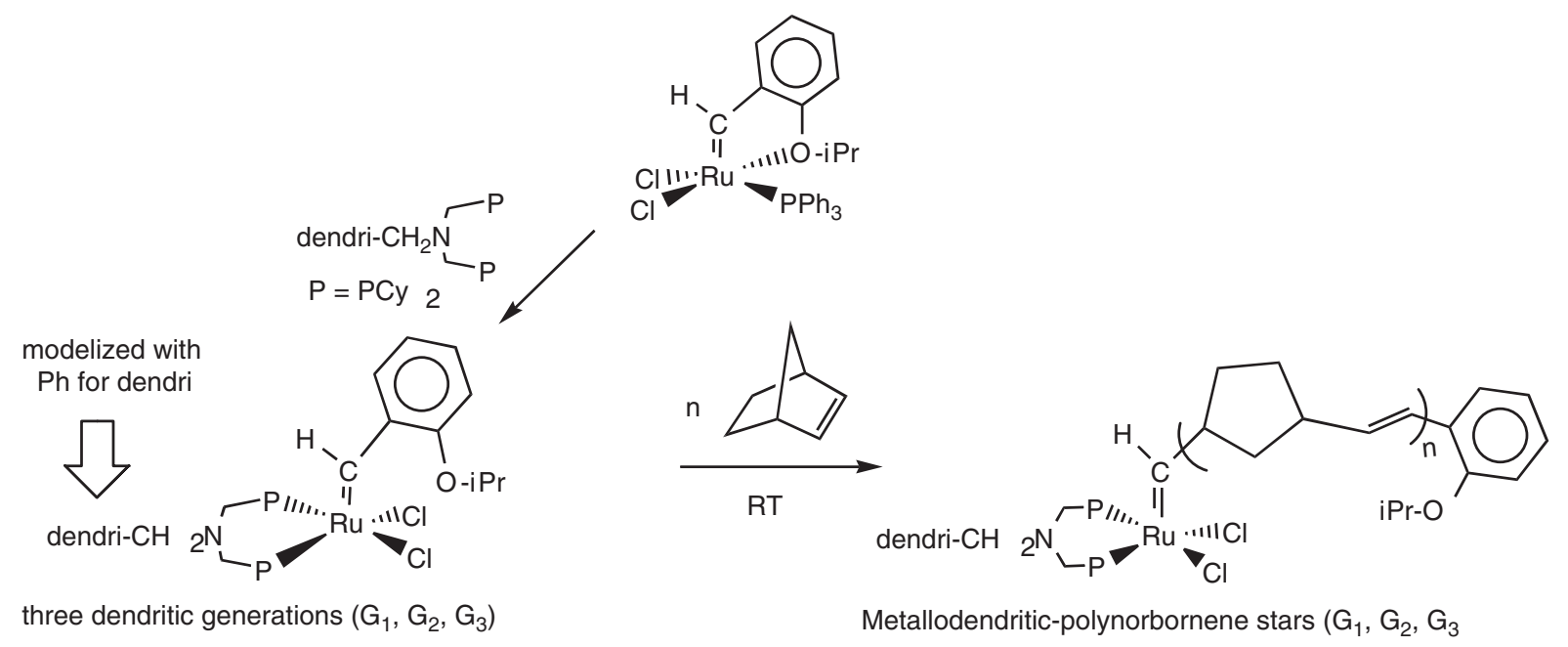

Scheme 4

Strategy for the ROMP of norbornene by Ru-benzylidene dendrimers to form dendrimer-cored stars.

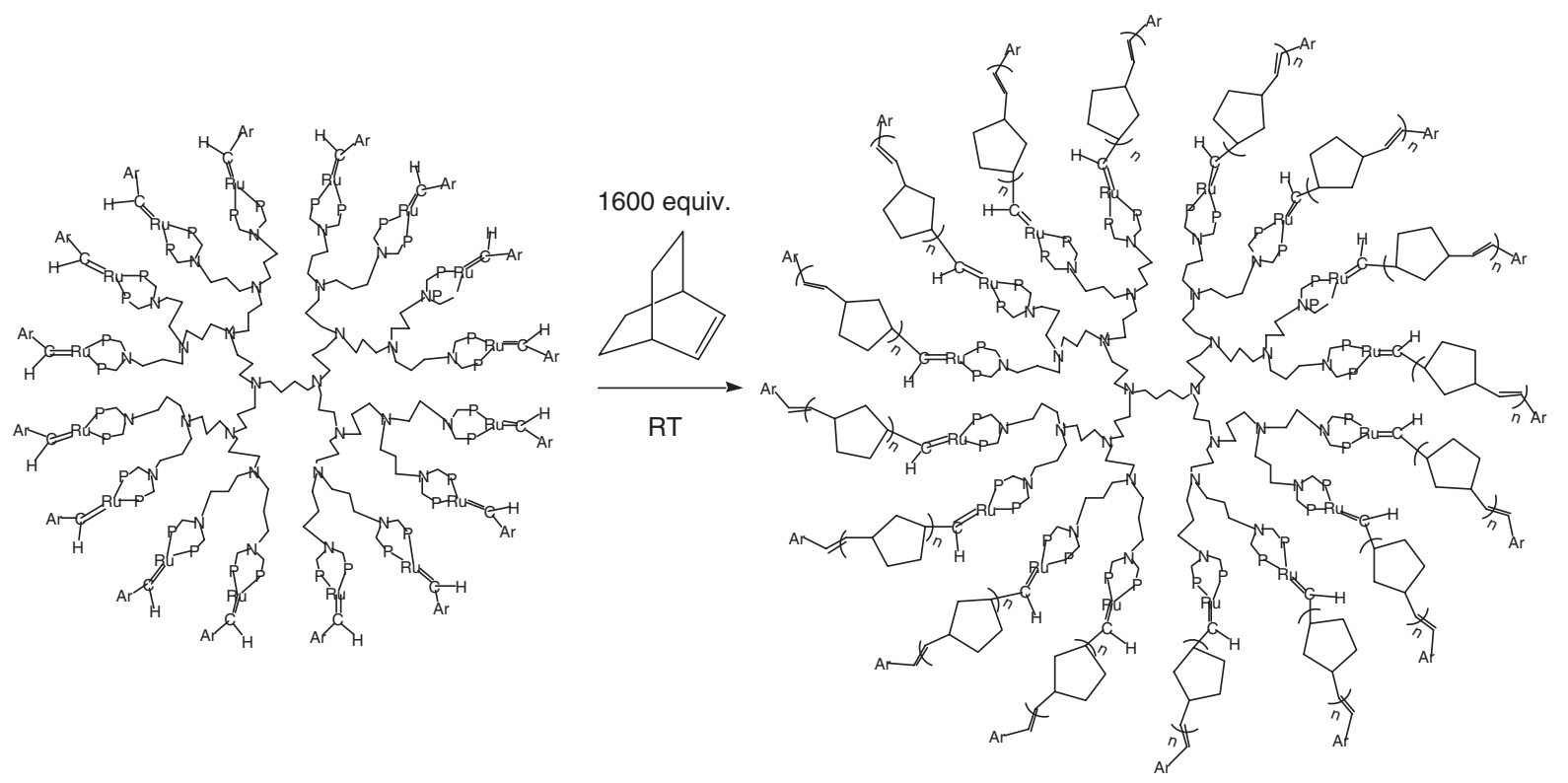

Equation 1

Third-generation ( $16 \mathrm{Ru}$ atoms) ruthenium-benzylidene dendrimer that catalyzes the ROMP of norbornene at $25^{\circ} \mathrm{C}$ to form dendrimer-cored stars.

\section{COMBINING CPFe+-INDUCED ARENE PERFUNCTIONALIZATION WITH OLEFIN METATHESIS}

The hexahapto complexation of arenes by the cationic group $\mathrm{CpFe}^{+}$considerably increases the acidity of its benzylic protons (the $p \mathrm{Ka}$ 's of the arenes in DMSO are lowered upon complexation with $\mathrm{CpFe}^{+}$by approximately 15 units, for instance from 43 to 28 for $\mathrm{C}_{6} \mathrm{Me}_{6}$ ) [24-26]. Therefore, deprotonation of the $\mathrm{CpFe}(\text { arene })^{+}$complexes is feasible under mild conditions with $\mathrm{KOH}$. Deprotonated $\mathrm{CpFe}(\operatorname{arene})^{+}$ complexes are good nucleophiles, and reactions with electrophiles such as the alkyl halides lead to the formation of new C-C bonds. Coupling the deprotonation and the nucleophilic reactions in situ in the presence of excess substrates leads to perfunctionalization in cascade multi-step reactions. When the electrophile is allyl bromide, polyolefin compounds are produced, and these compounds are ideal substrates for 


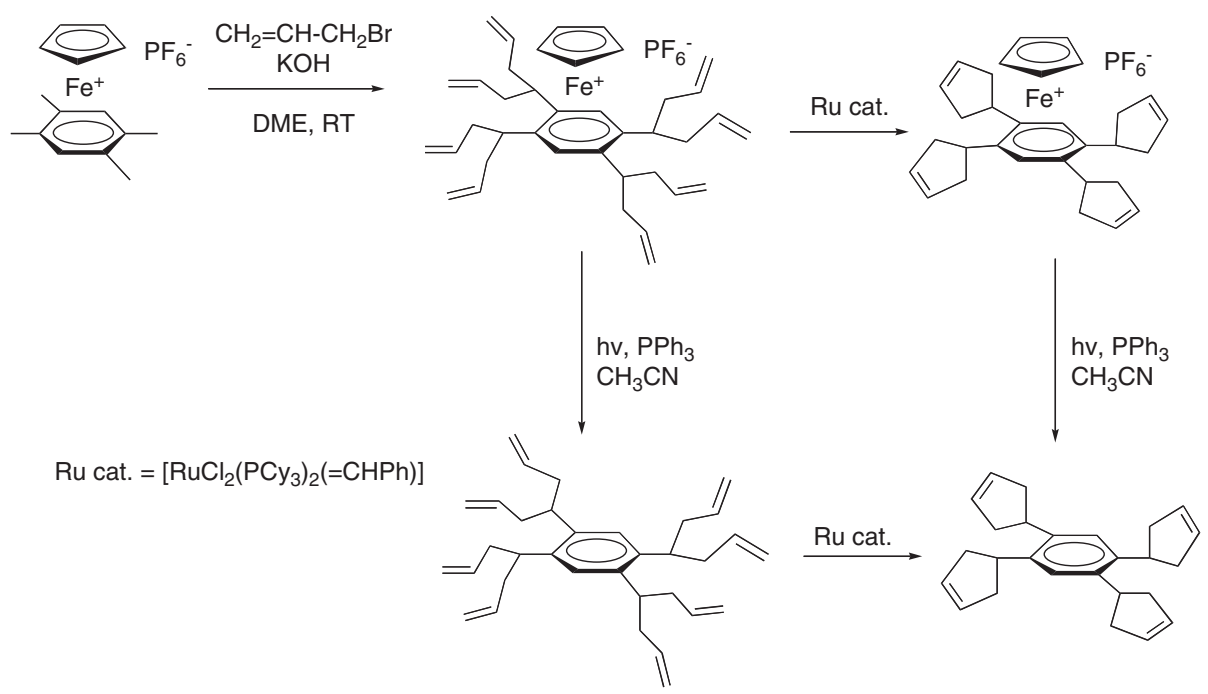

Scheme 5

$\mathrm{CpFe}^{+}$-induced octa-allylation of durene followed by RCM.

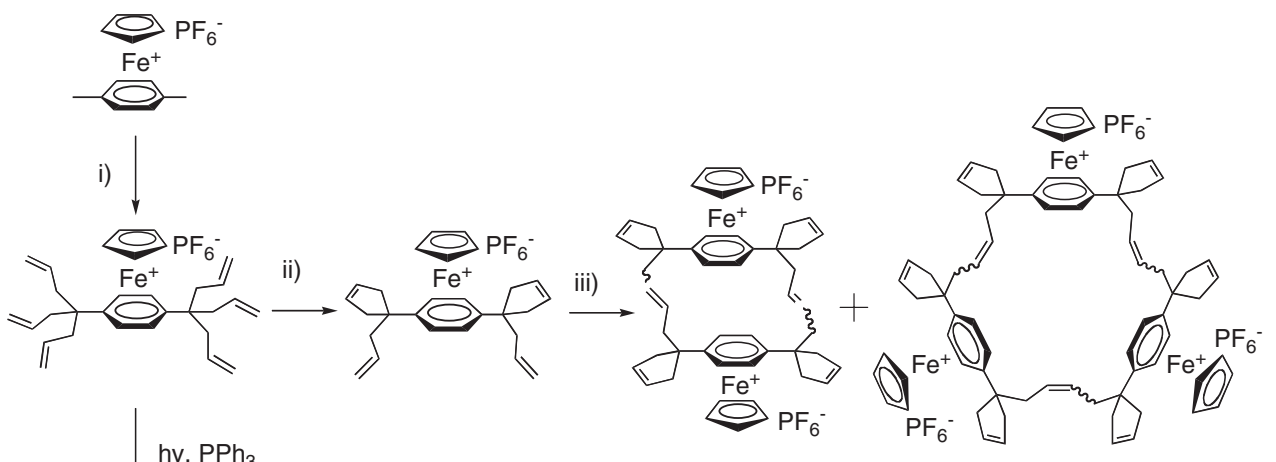

hv, $\mathrm{PPh}_{3}$
$\mathrm{CH}_{3} \mathrm{CN}$

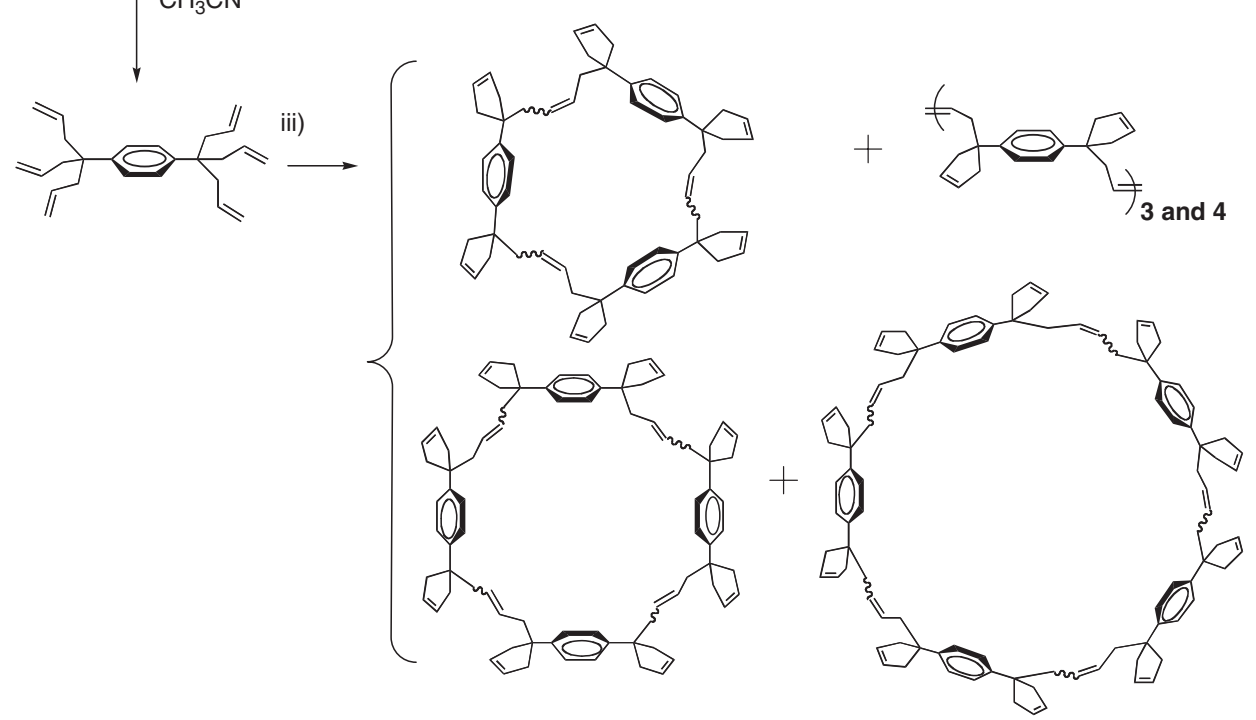

Scheme 6

Variety of structures obtained from $p$.xylene upon $\mathrm{CpFe}^{+}$-induced perallylation followed by olefin metathesis catalyzed by Grubb's catalysts $\left[\mathrm{RuCl}_{2}\left(\mathrm{PCy}_{3}\right)_{2}(=\mathrm{CHPh})\right]$ and $\left[\mathrm{Ru}\left(\mathrm{PCy}_{3}\right)\left\{\mathrm{C}(\mathrm{N}(\text { mesityl }) \mathrm{CH})_{2}\right\} \mathrm{Cl}_{2}(=\mathrm{CHPh})\right]$.

i) Allyl bromide, $\mathrm{KOH}, \mathrm{DME}$; ii) $\left[\mathrm{Ru}\left(\mathrm{PCy}_{3}\right)_{2} \mathrm{Cl}_{2}(=\mathrm{CHPh})\right], \mathrm{CH}_{2} \mathrm{Cl}_{2}, \mathrm{RT}$; iii) $[\mathrm{Ru}(\mathrm{PCy} 3)\{\mathrm{C}(\mathrm{N}($ mesityl $) \mathrm{CH}) 2\} \mathrm{Cl} 2(=\mathrm{CHPh})], \mathrm{C} 2 \mathrm{H} 4 \mathrm{Cl} 2,60^{\circ} \mathrm{C}$. 


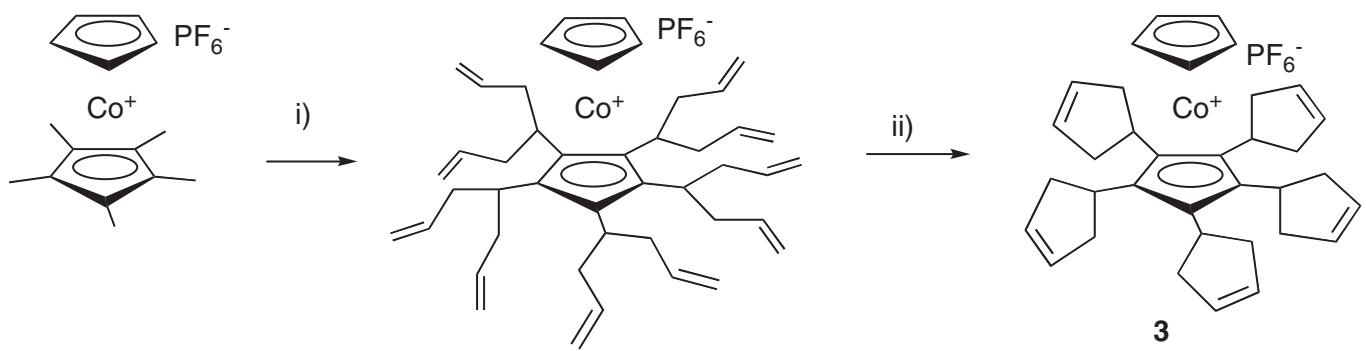

Scheme 7

Deca-allylation of pentametylcobaltocenium followed by quintuple RCM.

i) Allyl bromide, $\mathrm{KOH}$, DME; ii) $\left[\mathrm{Ru}\left(\mathrm{PCy}_{3}\right)_{2} \mathrm{Cl}_{2}(=\mathrm{CHPh})\right], \mathrm{CH}_{2} \mathrm{Cl}_{2}, \mathrm{RT}$.

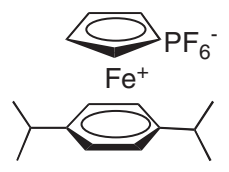

4

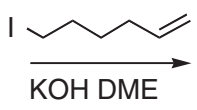

KOHDME

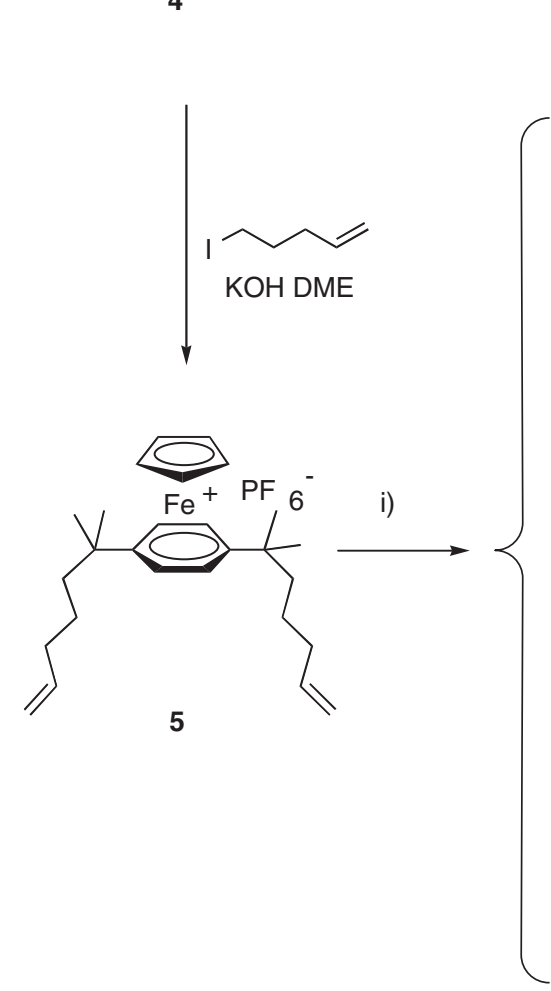

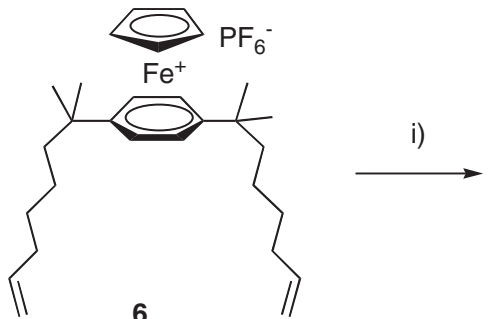

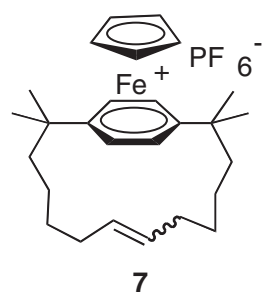

7
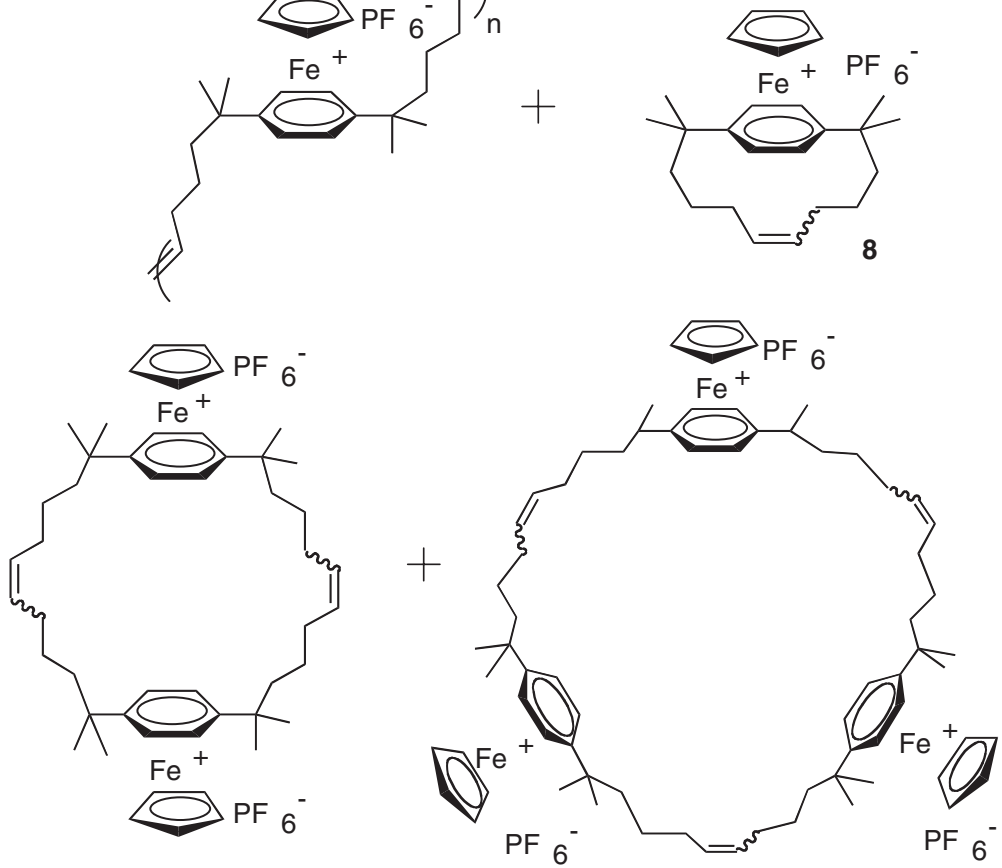

Scheme 8

Synthesis of $p$.cyclophane Fe complexes by RCM.

i) $\left[\mathrm{Ru}\left(\mathrm{PCy}_{3}\right)_{2} \mathrm{Cl}_{2}(=\mathrm{CHPh})\right], \mathrm{CH}_{3} \mathrm{Cl}, \mathrm{RT}$. 
ring closing metathesis (RCM) and cross metathesis (CM). For instance, below are shown new structures that were obtained using this strategy with durene (Scheme 5), p.xylene (Scheme 6), mesitylene (Scheme 8), and pentamethylcobaltocenium (Scheme 7) [26-29].

Pentamethylcobalticinium was perallylated to yield a deca-allylated cobalticinium, and then RCM of the organometallic complex proceeded to afford a pentacyclopentelylcyclopentadienyl Co sandwich 3 complex using the catalyst $\left[\mathrm{Ru}\left(\mathrm{PCy}_{3}\right)_{2} \mathrm{Cl}_{2}(=\mathrm{CHPh})\right][12]$.

The complex $\left[\mathrm{CpFe}(p \text {-diisopropylbenzenze })^{+}\right]\left[\mathrm{PF}_{6}{ }^{-}\right], \mathbf{4}$, (Scheme 8) is ideal for building a family of $p$-dialkenylaryl derivatives. In order to obtain organometallic $[n]$ paracyclophanes, dialkenyl complex were synthesized with longer chains. Dialkenylation of the $p$-diisopropylbenzene complex 4 with a $\omega$-alkenyl halide allowed the preparation of a large variety of para disubstituted substrates and intramolecular metathesis led to the desired paracyclophanes. Dialkenylation with 5-bromopentene or 6-bromohexene gave 5 and $\mathbf{6}$ respectively. Using $\left[\mathrm{RuCl}_{2}\left(\mathrm{PCy}_{3}\right)_{2}(=\mathrm{CHPh})\right]$ as catalyst in chloroform at room temperature, the substrate 5 led to a mixture of linear oligomers (2 to 6 units) and mono-, bi- and trimetallic paracyclophanes identified by their molecular peaks in the MALDI TOF mass spectrum. On the other hand,
6, containing alkenyl chains that are one methylene unit longer than in 45, selectively led to the cyclophane product $\mathbf{7}$. In the ${ }^{1} \mathrm{H}$ NMR spectra of $\mathbf{8}$, the signals of the $\beta$-hydrogens of the cyclophanes are shifted at $0.51 \mathrm{ppm}$ because of the aromatic anisotropy [30].

The activation of mesitylene upon complexation by the $\mathrm{CpFe}^{+}$moiety in $\left[\mathrm{CpFe}(\text { mesitylene })^{+}\right]\left[\mathrm{PF}_{6}^{-}\right]$, followed by a one-pot perallylation yielded $\left[\mathrm{CpFe}\right.$ (nonaallylmesitylene) $\left.{ }^{+}\right]$ $\left[\mathrm{PF}_{6}{ }^{-}\right], 9$ (Scheme 9) $[25,26]$. First, triple RCM reaction catalyzed by $\left[\mathrm{RuCl}_{2}\left(\mathrm{PCy}_{3}\right)_{2}(=\mathrm{CHPh})\right]$ proceeds in ten minutes under ambient condition, and a tetracyclic intermediate iron arene complex was isolated. Furthermore and interestingly, when the metathesis reaction was carried out in refluxing dichloroethane and upon adding now the second-generation catalyst $\left[\mathrm{Ru}\left(\mathrm{PCy}_{3}\right)\left\{\mathrm{C}(\mathrm{N}(\text { mesityl }) \mathrm{CH})_{2}\right\} \mathrm{Cl}_{2}(=\mathrm{CHPh})\right]$, the di-iron cage compound $\mathbf{1 0}$ was formed. Similarly, the ironfree nonaallylated compound $\mathbf{1 1}$ gave, by metathesis catalyzed by $\left[\mathrm{Ru}\left(\mathrm{PCy}_{3}\right)\left\{\mathrm{C}(\mathrm{N}(\text { mesityl }) \mathrm{CH})_{2}\right\} \mathrm{Cl}_{2}(=\mathrm{CHPh})\right]$, the organic cage 12. After hydrogenation with $\mathrm{H}_{2} / \mathrm{Pd} / \mathrm{C}$ in $\mathrm{CH}_{2} \mathrm{Cl}_{2}$ of this tripled-bridged cage $\mathbf{1 2}$, a single hydrogenated product is isolated. Another very useful feature is that the organic cage formation can be totally inhibited in the presence of acrylic acid to produce the triacid compound $\mathbf{1 3}$ by more rapid stereoselective cross metathesis (Scheme 9) [31].
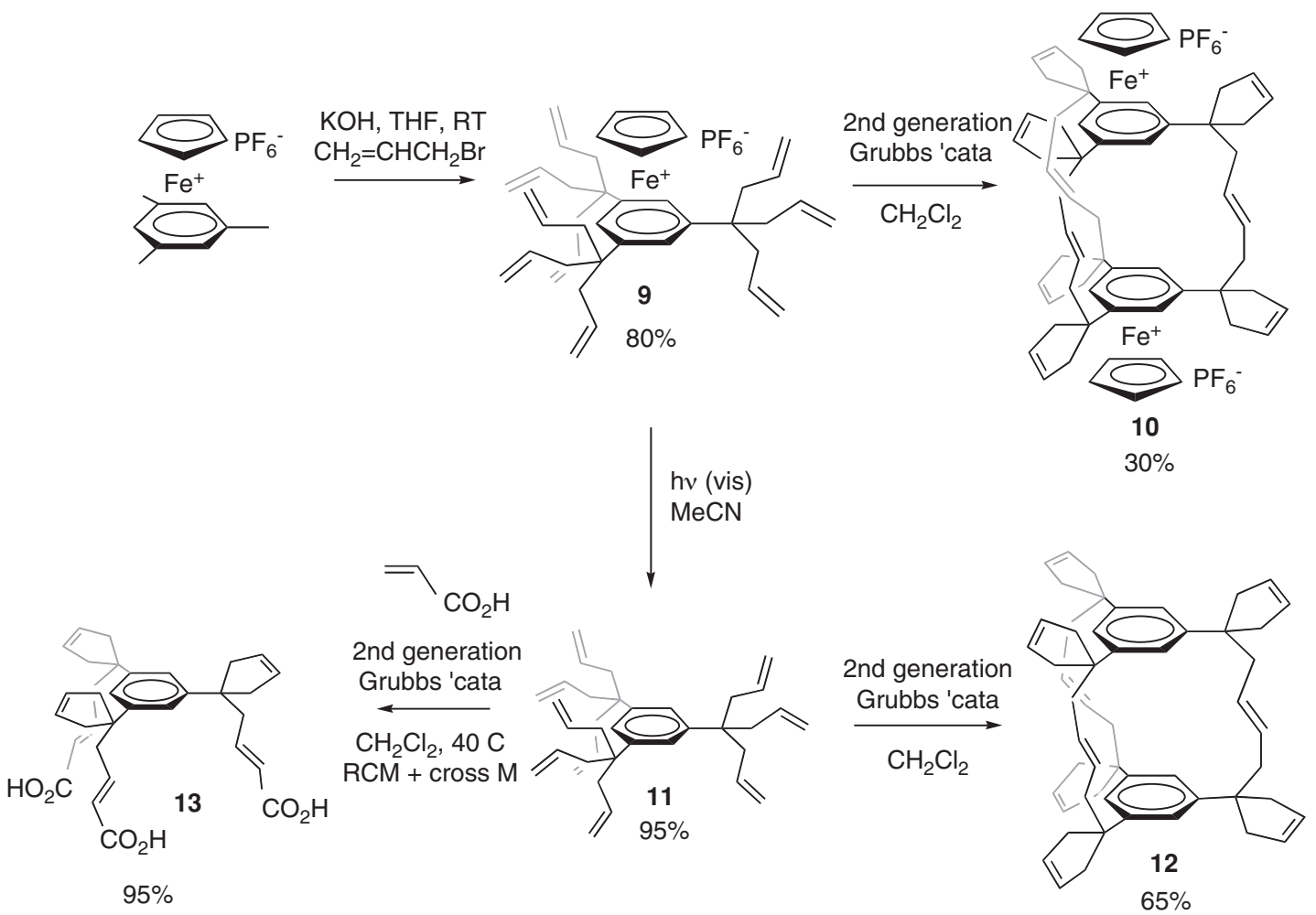

Scheme 9

$\mathrm{CpFe}$-induced nona-allylation of mesitylene followed by rapid $\mathrm{RCM}$ catalyzed by $\left[\mathrm{RuCl}_{2}\left(\mathrm{PCy}_{3}\right)_{2}(=\mathrm{CHPh})\right]$ and slow cage formation by cross metathesis catalyzed by the second-gereration Grubb's catalyst $\left[\mathrm{Ru}(\mathrm{PCy})_{3}\left\{\mathrm{C}(\mathrm{N}(\text { mesityl }) \mathrm{CH})_{2}\right\} \mathrm{Cl}_{2}(=\mathrm{CHPh})\right]$ vs. cross metathesis in the presence of acrylic acid (bottom, left). 

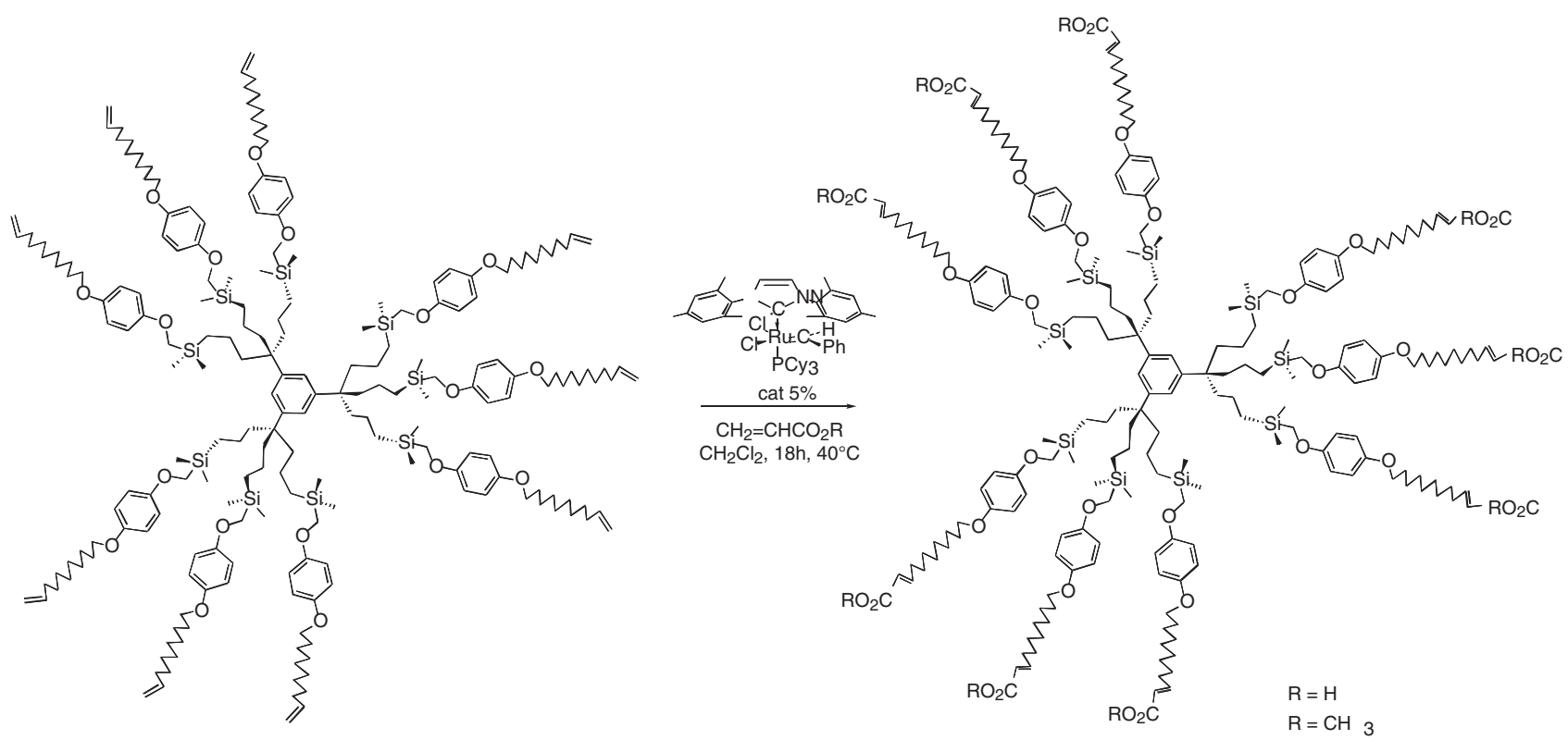

Scheme 10

Example of chemio-, regio- and steroselective cross metathesis of polyolefin dendrimers catalyzed by the 2nd generation Grubbs metathesis catalyst producing water-soluble dendrimers.

Since successful cross metathesis with acrylic acid gives water-soluble compounds, this reaction was exploited to synthesize water-soluble dendrimers with carboxylate termini. Denditic precursors were prepared with long tethers containing olefin termini so that no competitive RCM occurs unlike in the preceding example of Scheme 9. Indeed, CM of these longchain polyolefin dendrimers catalyzed by the 2 nd generation Grubbs metathesis catalyst proceeds selectively to produce dendrimers whose tethers are now terminated by carboxylic acid group (Scheme 10). The corresponding carboxylates are soluble in water. Higher generation dendrimers with carboxylic acid termini were synthesized in this way [30].

Other attempts have been reported in the literature for metathesis of polyolefin dendrimers or star compounds, and ring-closing metathesis products were formed. For instance, a third generation Fréchet-type dendrimer containing 24 allyl ether end-groups was synthesized by the Zimmerman group, cross-linked using the ring-closing metathesis (RCM) reaction, and the core was removed hydrolytically without significant fragmentation [31,32]. The results are analogous to those previously reported for homoallyl ether dendrimers suggesting that the less readily available homoallyl ether dendrimers can be replaced by their allyl ethers analogues [33]. The strategy consisting in performing RCM of branches and then removing the core has also been applied by the Peng group to nanoparticle-cored dendrimers [34-37].

\section{CONCLUDING REMARKS}

The engineering of nanostructures has considerably beneficited from olefin metathesis reactions as other areas of chemistry. Many rapid RCM reactions are carried out using the first generation of Grubb's catalyst, $\left[\mathrm{RuCl}_{2}\left(\mathrm{PCy}_{3}\right)_{2}(=\mathrm{CHPh})\right]$, whereas more difficult cage formation and cross metathesis reaction require the use of the second generation of Grubbs' ruthenium catalyst $\left[\mathrm{Ru}\left(\mathrm{PCy}_{3}\right)\left\{\mathrm{C}(\mathrm{N}(\text { mesityl }) \mathrm{CH})_{2}\right\} \mathrm{Cl}_{2}(=\mathrm{CHPh})\right]$. Introduction of ruthenium metathesis catalysts on the periphery of dendrimers is possible using a chelating phosphine, which lowers the metathesis activity but insures excellent framework stability. Such dendritic metathesis catalysts do not achieve RCM reactions, because the cis coordination of the diphosphine lowers the catalytic activity. ROMP of norbornene proceeds smoothly with such metallodendritic metathesis catalysts, however, yielding dendrimer-cored star polymers with several generations of dendritic catalysts (up to $16 \mathrm{Ru}$ branches). Other types of polymerization such as that involving alkyne metathesis polymerization can also be useful to develop dendritic architectures. An example of such metathesis polymerization was highlighted at the beginning of this review, illustrating the dramatically efficient acceleration of a catalytic process of an 18-electron tungsten catalyst upon coupling with an electron-transfer-chain catalyst. 
Work along several of these lines is in progress in our laboratory. In conclusion, alkene and alkyne metathesis are very useful reactions for the assembly of nanoarchitectures including dendritic ones with tailored properties.

\section{ACKNOWLEDGEMENTS}

This micro-review article is dedicated to our distinguished colleague Yves Chauvin. I should like to warmly thank all the students and colleagues who have contributed to our studies on dendrimer metathesis and whose names are found in the references. Financial support from the Institut Universitaire de France, the Université Bordeaux 1, the CNRS and the Ministère de la recherche et de la technologie is gratefully acknowledged.

\section{REFERENCES}

1 Chauvin, Y. and Hérisson, J.-L. (1971) Makromol. Chem., 141, 161 .

2 Chauvin, Y. (2006) Angew. Chem. Int. Edit., 45, 3740.

3 Schrock, R.R. (2006) Angew. Chem. Int. Edit., 45, 3748.

4 Grubbs, R.H. (2006) Angew. Chem. Int. Edit., 45, 3760.

5 Grubbs, R.H. (éd.) (2002) Handbook of metathesis, WileyVCH, Weinheim, Vols. 1-3.

6 For applications in total synthesis, see reference 5, Vol. 2 and, Nicolaou, K.C., Bulger, P.G. and Sarlah, D. (2005) Angew. Chem. Int. Edit., 44, 4490.

7 For applications in polymer chemistry, see reference 5, Vol. 3 and Buchmeiser, M.R. (2000) Chem. Rev., 100, 1565

8 For a historical account, see: Astruc, D. (2005) New J. Chem., 29, 42.

9 Astruc, D. (2007) Organometallic Chemistry and Catalysis, Springer, Berlin.

10 a) Katz, T.J. and Lee, S.J. (1980) J. Am. Chem. Soc., 102, 422; Clarke, T.C., Yannoni, C.S. and Katz, T.J. (1983) J. Am. Chem. Soc., 105, 7787; Katz, T.J., Ho, T.H., Shih, N.Y., Ying, V.C. and Stuart, Y.I.W. (1984) J. Am. Chem. Soc., 106, 2659; b) Tate, D.P., Knipple, W.R. and Augl, J.M. (1962) Inorg. Chem., 1, 433; Tate, D.P., Buss, A. and Augl, J. (1963) Inorg. Chem., 2, 427.

11 Desbois, M.-H. and Astruc, D., Chem. Commun. 1988, 472; Desbois, M.-H. and Astruc D. (1989) New J. Chem., 13, 595; Desbois, M.-H., Astruc, D., Guillin, J., Varret, F., Trautwein, A.X. and Villeneuve, G. (1989) J. Am. Chem. Soc., 111, 5800; Astruc, D. (1995) Electron-Transfer and Radical Reactions in Transition Metal Chemistry, VCH, New York, Chap. 6.

12 For the original ETC catalysis concept and use, see: Rich, R.L. and Taube, H. (1954) J. Am. Chem. Soc., 76, 2608.

13 For analysis of the physical parameters of ETC catalytic ligand substitution in organometallic chemistry, see: Ziegelman, P.M., Amatore, C. and Kochi, J.K. (1984) J. Am. Chem. Soc., 106, 3771; Kochi, J.K. (1986) J. Organomet. Chem., 300, 139.
14 Wijkens, P., Jastrzebski, J.T.B.H., van der Schaaf, P.A., Kolly, R., Hafner, A. and van Koten, G. (2000) Org. Lett., 2, 1621; Garber, S.B., Kingsbury, J.S., Gray, B.L. and Hoveyda, A.H. (2000) J. Am. Chem. Soc., 122, 8168; Beerens, H., Verpoort, F. and Verdonck, L. (2000) J. Mol. Cat., 151, 279; 159, 197.

15 Sanford, M.S., Ulman, M. and Grubbs, R.H. (2001) J. Am. Chem. Soc., 123, 749; Trnka, T.M. and Grubbs, R.H. (2001) Accounts Chem. Res., 34, 18.

16 Hansen, S.M., Volland, M.A.O., Rominger, F., Eisenträger, F. and Hofmann, P. (1999) Angew. Chem. Int. Edit. Engl., 38, 1273; Hansen, S., Rominger, F., Metz, M. and Hofmann, P. (1999) Chem. Eur. J., 5, 557; Adlhart, C., Volland, M.A.O., Hofmann, P. and Chen, P. (2000) Helv. Chim. Acta, 83, 3306; Amoroso, D. and Fogg, D.E. (2000) Macromolecules, 33, 2815; Six, C., Beck, K., Wegner, A. and Leitner, W. (2000) Organometallics, 19, 4639.

17 Reetz, M.T., Lohmer, G. and Schwickardi, R. (1997) Angew. Chem., Int. Edit. Engl., 36, 1526.

18 Alonso, E. and Astruc, D. (2000) J. Am. Chem. Soc., 122, 3222.

19 Kingsbury, J., Harrity, J.P.A., Bonitatebus, P.J. and Hoveyda, A.H. (1999) J. Am. Chem. Soc., 121, 791.

20 Gatard, S., Nlate, S., Cloutet, E., Bravic, G., Blais, J.-C. and Astruc, D. (2003) Angew. Chem. Int. Edit., 42, 452.

21 Gatard, S., Kahlal, S., Méry, D., Nlate, S., Cloutet, E., Saillard, J.-Y. and Astruc, D. (2004) Organometallics, 23, 1313.

22 Méry, D. and Astruc, D. (2005) J. Mol. Catal. A-Chem., 227, 1.

23 Lemo, J., Heuzé, K. and Astruc, D. (2005) Org. Lett., 7, 2253; Astruc, D., Heuze, K., Gatard, S., Méry, D., Nlate, S. and Plault, L. (2005) Adv. Synth. Catal., 347, 329; Heuze, K., Méry, D., Gauss, D. and Astruc, D. (2003) Chem. Commun., 2274; Heuzé, K., Méry, D., Gauss, D., Blais, J.-C. and Astruc, D. (2004) Chem. Eur. J., 10, 3936.

24 Trujillo, H.A., Casado, C.M., Ruiz, J. and Astruc, D. (1999) J. Am. Chem. Soc., 121, 5674; Trujillo, H.A., Casado, C.M. and Astruc, D. (1995) J. Chem. Soc., Chem. Commun., 7; Moulines, F. and Astruc, D. (1988) Angew. Chem. Int. Edit., 27, 1347; Catheline, D. and Astruc, D. (1983) J. Organomet. Chem., 248, C9; Astruc, D., Blais, J.-C., Cloutet, E., Djakovitch, L., Rigaut, S., Ruiz, J., Sartor, V. and Valério, C. (2000) Top. Curr. Chem., 120, 229.

25 Astruc, D., Nlate, S. and Ruiz, J. (2002) In Modern Arene Chemistry, Astruc, D. (éd.), Wiley-VCH, Weinheim, p. 400.

26 Sartor, V., Djakovitch, L., Fillaut, J.-L., Moulines, F., Neveu, F., Marvaud, V., Guittard, J., Blais, J.-C. and Astruc, D. (1999) J. Am. Chem. Soc., 121, 2929.

27 Martinez, V., Blais, J.-C. and Astruc, D. (2002) Org. Lett., 4, 651.

28 Martinez, V., Blais, J.-C. and Astruc, D. (2003) Angew. Chem. Int. Edit., 42, 4366.

29 Martinez, V., Blais, J.-C., Bravic, G. and Astruc, D. (2004) Organometallics, 23, 861; Lacoste, M., Rabaa, H., Astruc, D., Le Beuze, A., Saillard, J.-Y. and Précigoux, G. (1989) Organometallics, 8, 2233.

30 Ornelas, C., Méry, D., Ruiz Aranzaes, J., Blais, J.-C., Cloutet, E. and Astruc, D. (2005) Angew. Chem. Int. Edit., 44, 7399 . 
31 Beil, J.B., Lemcoff, N.G. and Zimmerman, S.C. (2004) J.Am. Chem. Soc., 126, 13576.

32 Lemcoff, N.G., Spurlin, T.A., Gewirth, A.A., Zimmerman, S.C., Beil, J.B., Elmer, S.L. and Vandeveer, G. (2004) J. Am. Chem. Soc., 126, 11420.

33 Wendland, M.S. and Zimmerman, S.C. (1999) J. Am. Chem. Soc., 121, 1389.

34 Aldama, J., Wang, Y. and Peng, X. (2001) J. Am. Chem. Soc., 8844.
35 Wang, Y.A., Li, J.J., Chen, H. and Peng, X. (2002) J. Am. Chem. Soc., 124, 2293.

36 Guo, W., Li, J.J. and Wang, X. (2003) J. Am. Chem. Soc., 125, 3901 .

$37 \mathrm{Gu}, \mathrm{W}$. and Peng, X. (2003) in Dendrimers and Nanosciences, C. R. Chimie, Astruc D. (éd.), Elsevier, Paris, 8-10, pp. 989-997.

Final manuscript received in March 2007 